\title{
Atypical, but Not Typical, Antipsychotic Drugs Increase Cortical Acetylcholine Release without an Effect in the Nucleus Accumbens or Striatum
}

Junji Ichikawa, M.D., Ph.D., Jin Dai, M.D., Ian A. O'Laughlin, B.S., Wiley L. Fowler, M.S., and Herbert Y. Meltzer, M.D.

The role of acetylcholine (ACh) in the action of antipsychotic drugs (APDs) was studied by microdialysis, without AChesterase inhibition, to facilitate the interpretation of any observed drug effects. The atypical APDs, clozapine (2.5-20 mg/kg), olanzapine (10 mg/kg), risperidone $(1 \mathrm{mg} / \mathrm{kg})$, and ziprasidone $(3 \mathrm{mg} / \mathrm{kg})$ significantly increased ACh release in rat medial prefrontal cortex (mPFC), whereas the typical APDs, haloperidol $(0.1-1 \mathrm{mg} / \mathrm{kg}), S(-)$-sulpiride (10-25 $\mathrm{mg} / \mathrm{g})$, and thioridazine $(5-20 \mathrm{mg} / \mathrm{kg})$ did not. None of seven APDs increased ACh release in the nucleus accumbens or striatum at the doses effective in the mPFC. Thus, atypical and typical APDs may differ in the ability to increase cortical ACh release, a possible factor contributing to cognitive improvement in schizophrenia. After perfusion with neostigmine, an AChesterase inhibitor, clozapine, but not haloperidol, increased ACh release in all three aforementioned brain regions with an enhanced effect in the $m P F C$, indicating the importance of studying ACh release in the absence of AChesterase inhibition. Clozapine, and perhaps other atypical APDs, alone or in combination with an AChesterase inhibitor, may improve cognition in schizophrenia, and perhaps other cognitive disorders, e.g., early Alzheimer's disease, by enhancing cortical cholinergic transmission.

[Neuropsychopharmacology 26:325-339, 2002] (C) 2002 American College of Neuropsychopharmacology. Published by Elsevier Science Inc.
KEY WORDS: Typical and atypical antipsychotic drugs; Acetylcholine release; Medial prefrontal cortex; Nucleus accumbens; Striatum; Schizophrenia

Acetylcholine (ACh) plays an important role in motor function and various domains of cognition, e.g., attention (Perry et al. 1999) and working memory (Winkler et

From the Departments of Psychiatry and Pharmacology, Vanderbilt University School of Medicine, Nashville, TN, USA.

Address correspondence to: Dr. J. Ichikawa, 1601 23rd Avenue South, The First Floor Laboratory R-1117, The Psychiatric Hospital at Vanderbilt, Nashville, TN 37212, USA.

Received 23 March 2001; revised 14 June 2001; accepted 13 July 2001.

Online publication: 7/9/01 at www.acnp.org/citations/Npp 071001147. al. 1995), and thus, may be important to either the cognitive dysfunction of schizophrenia or the ability of antipsychotic drugs (APDs) to improve some or all aspects of that cognitive deficit (Meltzer and McGurk 1999). The atypical APDs, clozapine, olanzapine, risperidone, and quetiapine, have, in fact, been reported to improve some domains of cognitive dysfunction (see Meltzer and McGurk 1999; Purdon 1999 for reviews), in addition to psychopathology (Leucht et al. 1999) in schizophrenia, more so than typical APDs, e.g., haloperidol and phenothiazines. The basis for these advantages is unclear.

The atypical APDs share in common a relatively more potent antagonist action at serotonin $(5-\mathrm{HT})_{2 \mathrm{~A}}$ compared to dopamine (DA) $\mathrm{D}_{2}$ receptors (Meltzer et 
al. 1989; Schotte et al. 1996) and $\alpha_{1}$ - and $\alpha_{2}$-adrenoceptors (Hertel et al. 1999). These features have been related to their ability to increase DA release in the mPFC (Hertel et al. 1999; Kuroki et al. 1999; Ichikawa et al. 2001). However, a possible role for ACh in mediating these effects is receiving increasing attention. Clozapine and olanzapine, but not risperidone, quetiapine, ziprasidone, or iloperidone (Schotte et al. 1996; Bymaster et al. 1999), have significant direct agonist or antagonist effects upon various subtypes of muscarinic $\mathrm{ACh}$ receptors (mAChRs) (Tandon 1999), whereas the typical APDs, thioridazine and mesoridazine, are also potent $\mathrm{mAChR}$ antagonists (Niedzwiecki et al. 1989a,b; Bolden et al. 1992). Furthermore, trihexyphenidyl and biperiden (Bolden et al. 1992), mAChR antagonists which reduce typical APD-induced extrapyramidal symptoms (EPS), have been reported to cause complex clinical effects in patients with schizophrenia, e.g., working memory impairment (King 1990) and worsening of psychosis while decreasing negative symptoms (Tandon et al. 1992). It is possible that clozapine and olanzapine influence clinical symptoms in schizophrenia via a direct effect upon main cholinergic transmission (Zorn et al. 1994; Bymaster et al. 1996).

As has been demonstrated in rodents (Everitt and Robbins 1997) and primates (Mrzljak et al. 1995), the nucleus basalis magnocellularis (NBM) or the basal forebrain consisting of the substantia innominata, the nucleus of Meynert, and the horizontal limb of the diagonal band, project cholinergic neurons to the cortex, whereas cholinergic interneurons exist mostly in the striatum (STR) and nucleus accumbens (NAC) (Kawaguchi et al. 1995). These three regions are involved in various actions of APDs (Ichikawa and Meltzer 1999): 1) the medial prefrontal cortex (mPFC) has been suggested to be involved in the neural circuitry important for negative symptoms and cognition, e.g., working memory (Goldman-Rakic and Selemon 1997); 2 ) the STR is centrally involved in motor function; and 3) the NAC plays a key role in both psychosis and reward (Davis et al. 1991; Kalivas and Nakamura 1999).

We have reported that some atypical APDs, e.g. clozapine, olanzapine, and risperidone, but not typical APDs, e.g., haloperidol and S(-)-sulpiride, increase DA release in the mPFC (Kuroki et al. 1999). However, drugs of other classes, e.g., antidepressants, which increase the release of DA (Tanda et al. 1994), but not ACh (Ichikawa et al. unpublished data) in the $\mathrm{MPFC}$, are not effective in the treatment of cognition and negative symptoms in schizophrenia (Plasky 1991). Thus, we postulate that the increases in $\mathrm{ACh}$ and DA release in the MPFC are responsible, in part, for the ability of these atypical APDs to improve cognition and negative symptoms in schizophrenia.

It has been reported that clozapine increases $\mathrm{ACh}$ release in mPFC, NAC, and STR, using microdialysis with neostigmine to increase basal $\mathrm{ACh}$ to detectable levels (Parada et al. 1997). Other investigators have also reported that clozapine (Imperato et al. 1993), haloperidol (Imperato et al. 1993, 1994; De Boer and Abercrombie 1996; Steinberg et al. 1998), and S(-)-sulpiride (Imperato et al. 1993, 1994; Ikarashi et al. 1997) increases ACh release in the STR. However, these effects of haloperidol (Osborne et al. 1994) and ( \pm )- or S(-)-sulpiride (De Boer et al. 1990; Westerink et al. 1990; Ueda et al. 1995) were not replicated. Neither haloperidol nor S(-)sulpiride has been reported to increase $\mathrm{ACh}$ release in mPFC or NAC (Moore et al. 1999).

It should be noted that all of these microdialysis studies employed various concentrations of AChesterase inhibitors, such as physostigmine and neostigmine, in the perfusion medium, in order to achieve reliable detection of $\mathrm{ACh}$ in the dialysate samples (see Ichikawa et al. 2000 for review). However, AChesterase inhibitors increase ACh concentrations in the extracellular space 30-100 fold (Maura and Raiteri 1986; Kawashima et al. 1994) which would be expected to cause persistent stimulation of muscarinic and nicotinic AChRs, and should alter the physiology of cholinergic transmission, making interpretation of the data problematic (Ichikawa et al. 2000). As discussed by Fujii et al. (1997), high concentrations of ACh stimulate feedback mechanisms, which inhibit ACh release via presynaptic $\mathrm{mACh}$ autoreceptors on cholinergic neuron terminals, and may also affect the activities of non-cholinergic neurons. These consideration provide a strong rationale for conducting microdialysis experiments in the absence of AChesterase inhibition, when possible, to determine the effect of various types of APDs on ACh release under more physiological conditions (De Boer and Abercrombie 1996; Di Chiara et al. 1996).

We have now developed a highly sensitive method to measure extracellular ACh in rat brain dialysate in the absence of AChesterase inhibitors (Ichikawa et al. 2000). With this method, we examined the effect of four atypical APDs (clozapine, olanzapine, risperidone, and ziprasidone), and three typical APDs (haloperidol, S(-)-sulpiride, and thioridazine), on ACh release in the $\mathrm{MPFC}, \mathrm{NAC}$, and STR.

\section{METHODS}

\section{Animals}

Male Sprague-Dawley albino rats (Zivic-Miller, Porterville, PA) weighing 250-350 g were housed two to three per cage and maintained in a controlled 12-12-h lightdark cycle and under constant temperature at $22^{\circ} \mathrm{C}$, with free access to food and water.

\section{Surgery}

Rats were anesthetized with an intraperitoneal injection (i.p.) of a combination of xylazine ( $13 \mathrm{mg} / \mathrm{kg}$; Rompun; 
Shawnee Mission, KS) and ketamine hydrochloride (87 $\mathrm{mg} / \mathrm{kg}$, Ketaset; Fort Dodge Lab, Fort Dodge, IA). One stainless guide cannula with a dummy probe was placed and fixed onto the cortex dorsal to either $\mathrm{MPFC}, \mathrm{NAC}$, or STR. Stereotaxic coordinates of each probe when implanted was $\mathrm{A}+3.2, \mathrm{~L}+0.8$ ( $10^{\circ}$ inclination), $\mathrm{V}-5.5 \mathrm{~mm}$ for the mPFC; A+0.5, L-4.0, V-5.5 for the STR and $\mathrm{A}+2.0, \mathrm{~L}+1.5 \sim 1.7, \mathrm{~V}-7.5 \mathrm{~mm}$ for the NAC, respectively, relative to bregma; incision bar level: $-3.0 \mathrm{~mm}$, according to the atlas of Paxinos and Watson (1986).

\section{Microdialysis}

Three to five days following cannulation surgery, a concentric-shaped dialysis probe $(2 \mathrm{~mm}$ length, polyacrylonitrile/sodium methalylsulfonate polymer membrane, AN69H; Hospal) was implanted into either mPFC, NAC, or STR under slight anesthesia with methoxyflurane (Metofane; Pitman-Moore, Mundelein, IL). Perfusion flow rate of the implanted probes was set at $1.5 \mu \mathrm{l} / \mathrm{min}$ and then dialysate samples $(45 \mu \mathrm{l})$ were collected every $30 \mathrm{~min}$. The perfusion medium was Dulbecco's phosphate buffered saline solution (Sigma) including $\mathrm{Ca}^{2+}$ $\left(\mathrm{NaCl} 138 \mathrm{mM}, \mathrm{Na}_{2} \mathrm{HPO}_{4} 8.1 \mathrm{mM}, \mathrm{KCl} 2.7 \mathrm{mM}, \mathrm{KH}_{2} \mathrm{PO}_{4}\right.$ $1.5 \mathrm{mM}, \mathrm{MgCl} 0.5 \mathrm{mM}, \mathrm{CaCl}_{2} 1.2 \mathrm{mM}, \mathrm{pH}$ 7.4). After stable baseline values in the dialysates were obtained, each drug or vehicle was administered to the rats. The effect of drugs was followed for at least another $180 \mathrm{~min}$. Dialysate samples were directly applied onto a HPLC with electrochemical detection assisted by a chromatography manager (Millennium; Waters, Milford, MA), and analyzed for ACh. The location of dialysis probes was verified after each experiment by brain dissection with 100 $\mu \mathrm{m}$ brain slices (OTS-4000; FHC, Bowdoinham, MD). The procedures applied in these experiments were approved by the Institutional Animal Care and Use Committee of Vanderbilt University in Nashville, TN, where we completed the present studies.

\section{Biochemical Assay}

We utilized a highly sensitive method to measure endogenous ACh in extracellular space in the absence of AChesterase inhibition (Ichikawa et al. 2000). In brief, dialysate samples were directly injected onto the liquid chromatography/electrochemistry (LCEC) system assisted by a chromatography manager (Millennium; Waters, Milford, MA), and analyzed for ACh. ACh was separated on a coiled cation exchanger ACh column (analytical column) (Sepstik $10 \mu \mathrm{m}$ ID $530 \times 1.0 \mathrm{~mm}$; BAS, West Lafayette, IN), followed by the post-IMER (immobilized enzyme reactor) (BAS), which consists of choline oxidase $(\mathrm{ChO}) /$ AChesterase. ACh was hydrolyzed by AChesterase to form acetate and choline in the post IMER. Then, choline was oxidized by $\mathrm{ChO}$ to produce betaine and hydrogen peroxide $\left(\mathrm{H}_{2} \mathrm{O}_{2}\right) \cdot \mathrm{H}_{2} \mathrm{O}_{2}$ was detected and reduced to $\mathrm{H}_{2} \mathrm{O}$ on an Unijet amperometric detector cell with a peroxidase-redox-coated glassy carbon electrode (MF-2098; BAS), set at $+100 \mathrm{mV}$ (LC$4 \mathrm{C}$; $\mathrm{BAS}$ ) versus $\mathrm{Ag} / \mathrm{AgCl}$ reference electrode.

This reduction was analyzed with the detector (LC$4 \mathrm{C}$; BAS) as signal indicating ACh in the chromatogram. However, it is difficult in most cases to separate the ACh peak from the huge choline peak with the analytical column. Therefore, a pre-IMER (BAS), which consists of $\mathrm{ChO}$ and catalase, was added prior to the analytical column. Choline in the dialysate samples was oxidized by $\mathrm{ChO}$ to form betaine and $\mathrm{H}_{2} \mathrm{O}_{2}$ by the preIMER. The $\mathrm{H}_{2} \mathrm{O}_{2}$ was then converted by the catalase to $\mathrm{H}_{2} \mathrm{O}$ before entering the analytical column. This procedure eliminates interference of the $\mathrm{ACh}$ peak in the chromatogram by choline, thereby decreasing the detection limit of ACh. The ACh peak is clearly resolvable and can be identified in all chromatograms (Figure 1A). The area and height of ACh peak showed a linear correlation with concentration. Due to the markedly increased signal-to-noise ratio, the detection limit was 2-3 fmol per sample (20 $\mu \mathrm{l}$ sample loop). The mobile phase $\left(\mathrm{Na}_{2} \mathrm{HPO}_{4} 50 \mathrm{mM}, \mathrm{pH}\right.$ 8.2) including ProClin (BAS), a microbiocide, was pumped at $0.14 \mathrm{ml} / \mathrm{min}$ by a LC10AD pump (Shimadzu, Kyoto, Japan). The reagents used were analytical or HPLC grade.

\section{Drugs}

Clozapine $\mathrm{HCl}$ (Sandoz, East Hanover, NJ), haloperidol (McNeil, Spring House, PA), olanzapine (Eli Lilly, Indianapolis, IN), risperidone (Janssen, Titasville, NJ), S(-)sulpiride (Research Biochemical Inc., Natick, MA), and M100907 (Hoechst Marion Roussel, Bridgewater, NJ) were each dissolved in a small amount of $0.1 \mathrm{~N} \mathrm{HCl}$ solution and the $\mathrm{pH}$ was adjusted to 6-7 with $0.1 \mathrm{~N}$ $\mathrm{NaOH}$. Ziprasidone mesylate (Pfizer, Groton, $\mathrm{CT}$ ) was dissolved in 45\% 2-hydroxypropyl- $\beta$-cyclodextrin (HBC) (Research Biochemical Inc., Natick, MA). Thioridazine $\mathrm{HCl}, \mathrm{S}(-)$ scopolamine $\mathrm{HBr}$, and oxotremorine sesquifumarate (Research Biochemical Inc., Natick, MA) were dissolved in deionized water. Vehicle or drugs were administered subcutaneously (s.c.). Neostigmine bromide and tetrodotoxin citrate (RBI) were each dissolved in the perfusion medium of Dulbecco's phosphate buffered saline. Receptor affinities of these seven APDs were summarized in Table 1.

\section{Data Analysis}

Only results derived from healthy rats with a correctly positioned dialysis probe were included in the data analysis. Repeated measure ANOVA (treatment $\times$ time) followed by Fisher's protected least significant difference post-hoc pairwise comparison procedure and one-way ANOVA were used to determine group dif- 
$\mathbf{A}$

\section{Chromatogram of Acetylcholine (ACh) in the mPFC}
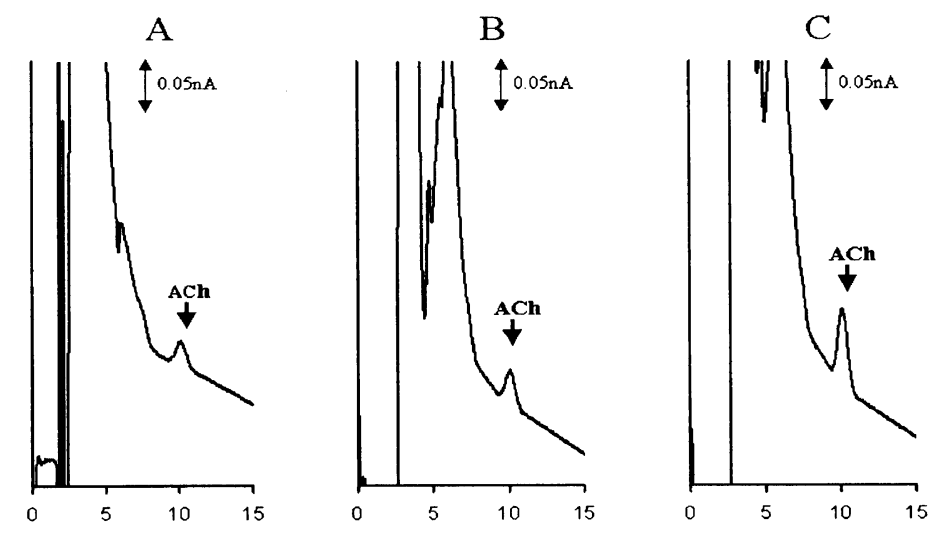

20 fmol ACh Standard
Basal ACh Release
B

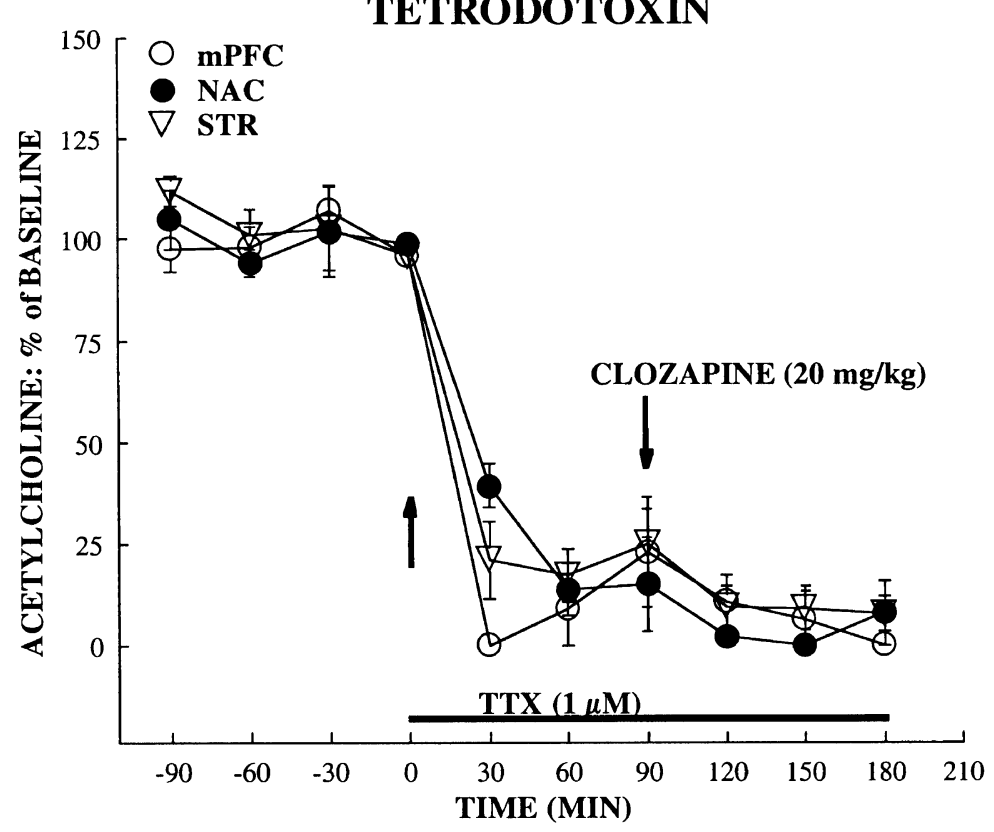

Figure 1. (A) Separation of ACh peak on the chromatograph obtained from authentic standard solution (20 fmol) and dialysate samples in the medial prefrontal cortex (mPFC). ACh peak was clearly separated and reliably detected in the chromatogram. Clozapine (CLOZ, $20 \mathrm{mg} / \mathrm{kg}$, s.c.) significantly increased the height and area of ACh peak compared to the basal peak. Detection limit was less than 2-3 fmol per sample. Vertical axis indicates $\mathrm{nA}$ and horizontal axis indicates time after injection ( $\mathrm{min}$ ), respectively. (B) Perfusion of tetrodotoxin (TTX, 1 $\mu \mathrm{M})$ into the dialysis probe immediately decreased basal dialysate ACh concentrations to approximately $10 \%$ of the baseline levels $(N=4)$. Administration of clozapine (20 $\mathrm{mg} / \mathrm{kg}$, s.c.) did not affect the TTXinduced decreases in ACh concentrations in the medial prefrontal cortex (mPFC, $O, N=$ $4)$, nucleus accumbens (NAC,,$N=4$ ), and striatum (STR, $\nabla, N=4)$. ferences (StatView 4.5 for the Macintosh). Mean values of four consecutive pre-drug dialysate levels were designated as $100 \%$. The net-AUC was calculated from the absolute net increase for a $0-180-\mathrm{min}$ period (six samples) or a $30-180-$ min period (five samples) after subtracting each pre-drug baseline value. The $\%$ net-AUC is the net-AUC value expressed as a percentage of each baseline AUC value. A $p<.05$ was considered significant in this study. All results are given as mean \pm S.E.

\section{RESULTS}

\section{Basal Levels}

Basal dialysate $\mathrm{ACh}$ concentrations in the absence of AChesterase inhibition were $19.5 \pm 0.7(\mathrm{fmol} / 20 \mu \mathrm{l})$ in the mPFC, $27.7 \pm 1.7$ in the NAC, and $54.7 \pm 3.4$ in the STR, respectively, and were not significantly different between treatment groups in each region (Table 2). The sodium channel blocker tetrodotoxin (TTX, $1 \mu \mathrm{M})$, given in the perfusion medium, rapidly decreased dialysate ACh concentrations to approximately $10 \%$ of basal levels in all regions. Clozapine $(20 \mathrm{mg} / \mathrm{kg}$, s.c.) had no effect on dialysate ACh concentrations in the mPFC, NAC or STR in the presence of TTX $(1 \mu \mathrm{M})$ (Figure 1B).

\section{Effects of Scopolamine and Oxotremorine in the Absence of AChesterase Inhibition}

The non-selective $\mathrm{mAChR}$ antagonist $\mathrm{S}(-)$-scopolamine $(0.16,0.5$, and $1.5 \mathrm{mg} / \mathrm{kg})$ increased dialysate ACh concentrations in the mPFC (Figure 2A), whereas S(-)-scopolamine $(0.5 \mathrm{mg} / \mathrm{kg})$ had no effect in the NAC or STR 
Table 1. Receptor Binding Affinity (Ki, nM) of Antipsychotic Drugs

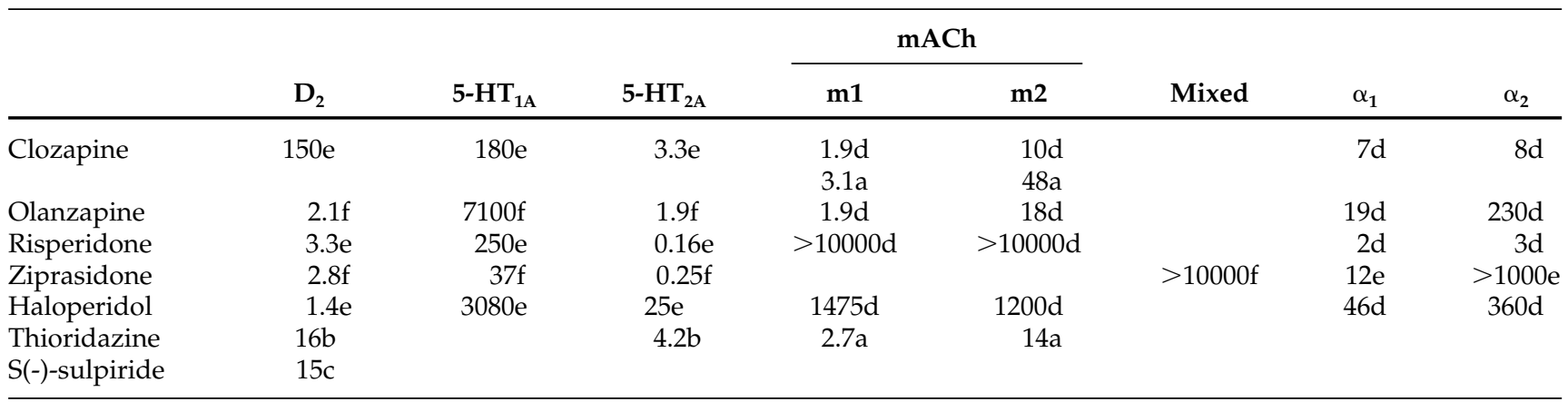

The Ki values for $\mathrm{D}_{2}, 5-\mathrm{HT}_{1 \mathrm{~A}}, 5-\mathrm{HT}_{2 \mathrm{~A}}, \mathrm{~m} 1, \mathrm{~m} 2$ and mixed $\mathrm{mACh}$ receptors in human and rat subtypes are from: $\mathrm{a}=\mathrm{Bolden}$ et al. $(1992) ; \mathrm{b}=\mathrm{Leysen}$ et al. (1993); c = Seeman and van Tol (1994); d = Bymaster et al. (1996); e = Schotte et al. (1996); and f = Arnt and Skarsfeldt (1998), respectively.

(Figures $2 \mathrm{~B}$ and 2C). Oxotremorine $(0.5,1.5$, but not $0.16, \mathrm{mg} / \mathrm{kg})$, a non-selective $\mathrm{mAChR}$ agonist, decreased dialysate $\mathrm{ACh}$ concentrations in the $\mathrm{MPFC}$, and in the NAC and STR as well, at $0.5 \mathrm{mg} / \mathrm{kg}$ (Figures 2D, $2 \mathrm{E}$, and $2 \mathrm{~F}$ ).

\section{Effects of Antipsychotics in the Absence of AChesterase Inhibition}

Atypical APDs, clozapine $(2.5,5,20$, but not $1.25, \mathrm{mg} /$ $\mathrm{kg}$, s.c.), olanzapine (10, but not 1 or $3, \mathrm{mg} / \mathrm{kg}$, s.c.), risperidone (1, but not 0.1 or $0.3, \mathrm{mg} / \mathrm{kg}$, s.c.), and ziprasidone (3, but not $1, \mathrm{mg} / \mathrm{kg}$, s.c.), in the absence of AChesterase inhibition, significantly increased dialysate $\mathrm{ACh}$ concentrations in the mPFC compared with vehicle controls (Figure 3). However, typical APDs, haloperidol (0.1 and $1 \mathrm{mg} / \mathrm{kg}$, s.c.), S(-)-sulpiride (10 and $25 \mathrm{mg} / \mathrm{kg}$, s.c.), and thioridazine (5 and $20 \mathrm{mg} / \mathrm{kg}$, s.c.) had no significant effect on dialysate ACh concentrations in the mPFC (Figure 4) compared with vehicle controls. On the other hand, none of these seven APDs at the effective doses in the $\mathrm{MPFC}$ had any significant effect on dialysate $\mathrm{ACh}$ concentrations in the NAC or
STR compared with vehicle controls (Figure 5). (Timecourse effects were not shown in the NAC and STR).

The effect of APDs on dialysate ACh concentrations in the mPFC, NAC, and STR was also analyzed with the $\%$ net-AUC (area under the curve) to clearly show a regional difference (Figure 5). In order to avoid the influence of an injection artifact (see below), a 30-180-min period (five samples) analysis is also provided. The pattern of results obtained with the $0-180-$ min and the 30180 -min periods were virtually identical.

\section{Effects of Neostigmine}

Inclusion of neostigmine $(0.03$ and $0.3 \mu \mathrm{M})$, an AChesterase inhibitor, in the perfusion medium markedly increased dialysate $\mathrm{ACh}$ concentrations in the $\mathrm{mPFC}$, NAC, or STR (Table 2). The increase in the NAC and STR was dose-dependent (not fully studied in the $\mathrm{MPFC}$ because we had already found that clozapine increases ACh release in the absence of neostigmine). The ability of $0.3 \mu \mathrm{M}$ neostigmine itself to increase $\mathrm{ACh}$ concentrations in the $\mathrm{mPFC}$ was almost equipotent to that of lower dose neostigmine $(0.03 \mu \mathrm{M})$ in the NAC and STR.

Table 2. Basal Dialysate Concentrations

\begin{tabular}{lcccc}
\hline Region & Neostigmine $(\mu \mathbf{M})$ & $\boldsymbol{n}$ & ACh $(\mathbf{f m o l} / \mathbf{2 0} \boldsymbol{\mu l})$ & Ratio \\
\hline mPFC & 0 & 127 & $19.5 \pm 0.7$ & \\
& 0.3 & 12 & $616 \pm 55$ & 31.5 \\
NAC & 0 & 45 & $27.7 \pm 1.7$ & \\
& 0.03 & 4 & $623 \pm 69$ & 91.6 \\
STR & 0.3 & 11 & $2537 \pm 334$ & \\
& 0 & 45 & $54.7 \pm 3.4$ & 73.8 \\
\hline
\end{tabular}

Abbreviations: $\mathrm{mPFC}=$ medial prefrontal cortex $; \mathrm{NAC}=$ nucleus accumbens; $\mathrm{STR}=$ striatum.

Ratio: ACh at $0.3 / 0 \mu \mathrm{M}$ Neostigmine. 


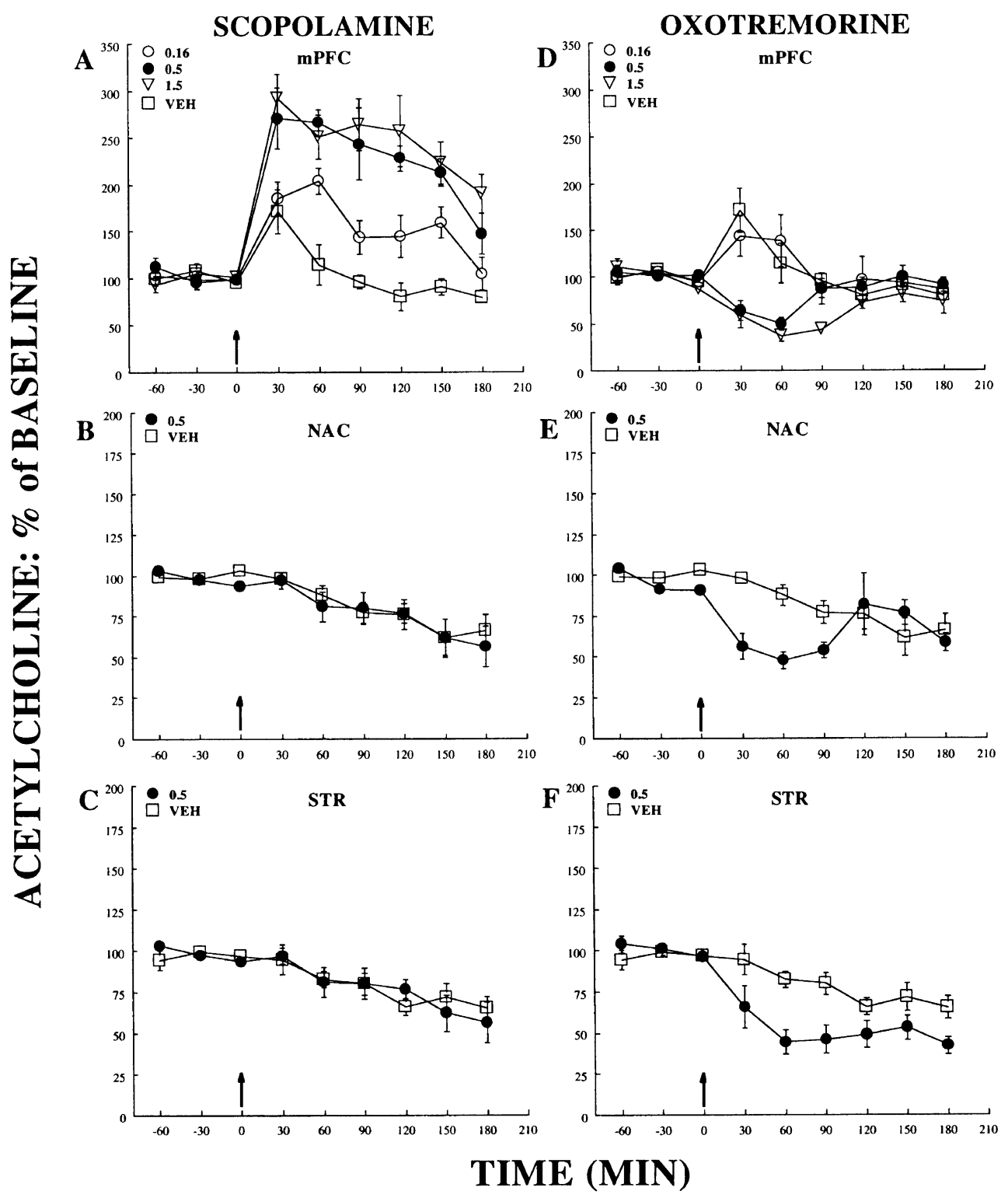

Figure 2. Time-course effects of S(-)-scopolamine and oxotremotrine, non-selective mAChR antagonist and agonist, respectively, compared with vehicle controls (VEH, $\square, N=8$ ) in the absence of AChesterase inhibition. (A) S(-)-scopolamine (0.16, 0.5 , and $1.5 \mathrm{mg} / \mathrm{kg}$ s.c.; $\bigcirc, \boldsymbol{O}$, and $\boldsymbol{\nabla}$, respectively) dose-dependently increased dialysate $\mathrm{ACh}$ concentrations in the $\mathrm{mPFC}(\mathrm{N}=$ $5-6)(\mathrm{F}(1,11)=18.99, p=.001 ; \mathrm{F}(1,12)=85.98, p<.001 ;$ and $\mathrm{F}(1,10)=63.67, p<.001$, respectively). (B) and (C) S(-)-scopolamine $(0.5 \mathrm{mg} / \mathrm{kg}, \mathbf{O})$ did not affect dialysate ACh concentrations in the NAC $(N=6)$ or STR $(N=6)(\mathrm{F}(1,11)=0.05, p=.82 ;$ and $\mathrm{F}(1,10)=0.11, p=.75$, respectively). (D) Oxotremorine $(0.5,1.5$, but not $0.16, \mathrm{mg} / \mathrm{kg}$, s.c.; $\bullet, \nabla$, and $\bigcirc$, respectively) significantly decreased dialysate ACh concentrations in the $\operatorname{mPFC}(N=5-6)(\mathrm{F}(1,11)=5.27, p=.042 ; \mathrm{F}(1,11)=13.37, p=.004 ;$ and $\mathrm{F}(1,12)=0.02, p=.89$, respectively). (E) Oxotremorine $(0.5 \mathrm{mg} / \mathrm{kg}, \mathbf{O})$ decreased them at the first three samples in the NAC $(N=6)(\mathrm{F}(1,11)=9.43, p=.011)$, although it had no significant effect in the six samples $(\mathrm{F}(1,11)=3.38, p=.09)$. (F) Oxotremorine $(0.5 \mathrm{mg} / \mathrm{kg}, \mathbf{O})$ significantly decreased dialysate ACh concentrations in the $\mathrm{STR}(\mathrm{N}=6)(\mathrm{F}(1,11)=32.14, p<.001)$

\section{Effects of Antipsychotics in the Presence of AChesterase Inhibition}

In the presence of $0.3 \mu \mathrm{M}$ neostigmine, clozapine (20 $\mathrm{mg} / \mathrm{kg}$, s.c.) significantly increased dialysate ACh concentrations in the NAC and STR, as well as the mPFC, compared with vehicle controls (Figures 6A, 6B, and 6C). The increase in dialysate $\mathrm{ACh}$ concentrations in the
mPFC produced by clozapine $(20 \mathrm{mg} / \mathrm{kg}$, s.c.) was potentiated two-to-three fold by the presence of neostigmine $(0.3 \mu \mathrm{M})$, compared to the increase in its absence (Figure 3). Neostigmine $0.3 \mu \mathrm{M}$ given in the perfusion medium did not affect the inability of haloperidol (1 $\mathrm{mg} / \mathrm{kg}$, s.c.) to increase dialysate ACh concentrations in the three regions in the absence of neostigmine, com- 

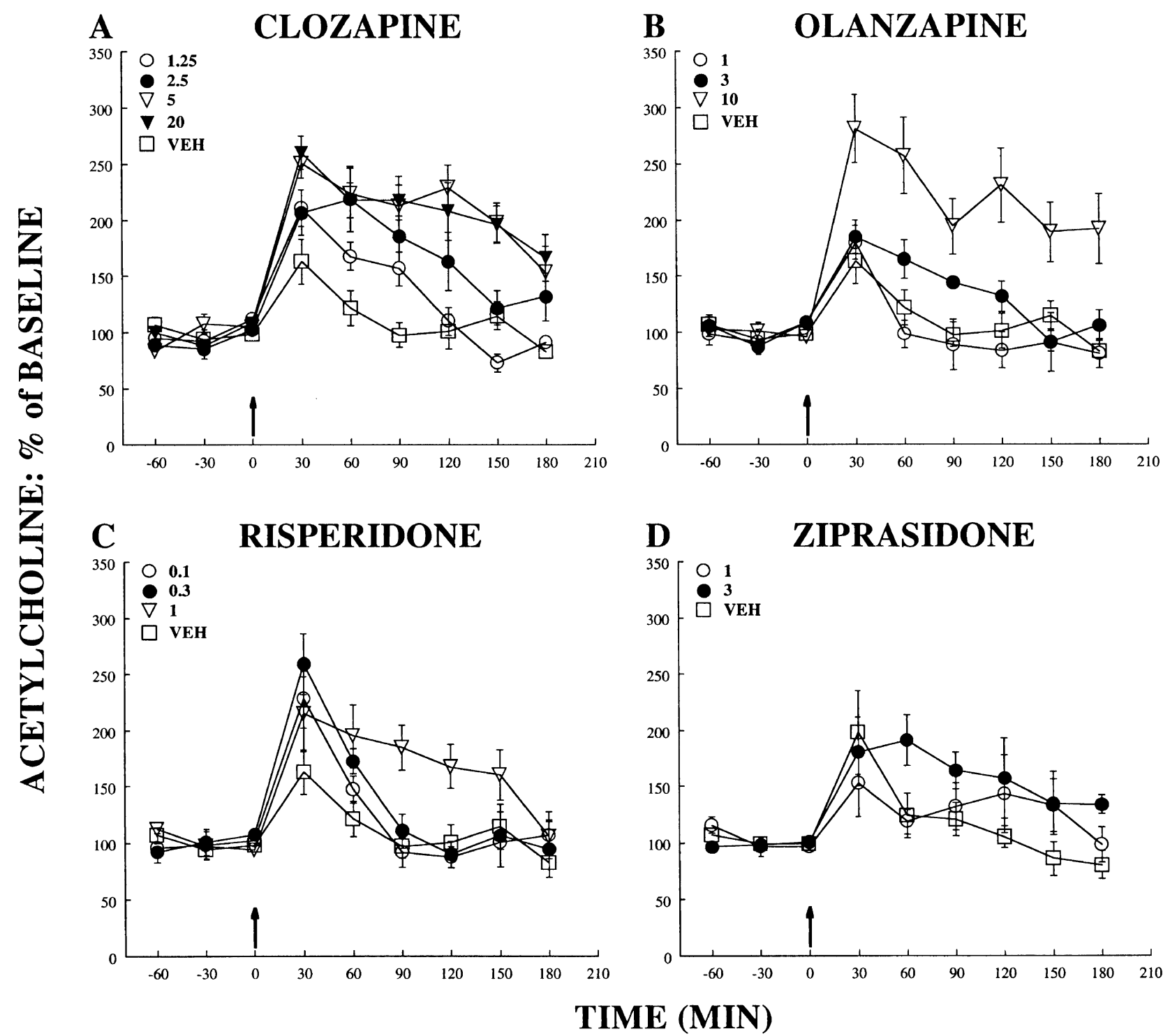

Figure 3. Time-course effects of atypical antipsychotic drugs in the medial prefrontal cortex (mPFC), compared with vehicle controls $(\mathrm{VEH}, \square)(\mathrm{N}=6-7)$ in the absence of AChesterase inhibition. Dialysate ACh concentrations were significantly increased by clozapine $(N=6)[(\mathbf{A}) 2.5,5,20$, but not $1.25, \mathrm{mg} / \mathrm{kg}$, s.c.; $\boldsymbol{\bullet}, \boldsymbol{\nabla}, \boldsymbol{\nabla}$, and $\bigcirc$, respectively] $(\mathrm{F}(1,10)=16.78, p=$ $.002 ; \mathrm{F}(1,10)=47.45, p<.001 ; \mathrm{F}(1,10)=34.29, p<.001 ;$ and $\mathrm{F}(1,10)=3.44, p=.09$, respectively), olanzapine $(\mathrm{N}=6-7)[(\mathrm{B})$ 10 , but not 1 or $3, \mathrm{mg} / \mathrm{kg}$, s.c.; $\boldsymbol{\nabla}, \bigcirc$, and $\bullet$, respectively] $(\mathrm{F}(1,11)=16.76, p=.002 ; \mathrm{F}(1,11)=0.30, p=.60 ;$ and $\mathrm{F}(1,10)=4.61$, $p=.058$, respectively), risperidone $(N=5-6)[(C) 1$, but not 0.1 or $0.3, \mathrm{mg} / \mathrm{kg}$, s.c., $\boldsymbol{\nabla}, \mathrm{O}$, and $\bullet$, respectively] $(\mathrm{F}(1,10)=6.19$, $p=.032 ; \mathrm{F}(1,10)=2.25, p=.16 ;$ and $\mathrm{F}(1,9)=4.53, p=.062$, respectively), and ziprasidone $(N=6)[(\mathrm{D}) 3, \mathrm{but}$ not $1, \mathrm{mg} / \mathrm{kg}$, s.c., $\bigcirc$ and $\bigcirc$, respectively] $(\mathrm{F}(1,10)=7.21, p=.023$; and $\mathrm{F}(1,10)=0.49, p=.50$, respectively)

pared with vehicle controls (Figures 6D, 6E, and 6F). Since preliminary data demonstrated that clozapine (20 $\mathrm{mg} / \mathrm{kg}$ ) had no significant effect on dialysate ACh concentrations in the NAC or STR in the presence of a lower dose of neostigmine $(0.03 \mu \mathrm{M})$, we did not further examine the effect of $0.03 \mu \mathrm{M}$ neostigmine on the ability of clozapine $(20 \mathrm{mg} / \mathrm{kg})$ to increase dialysate ACh concentrations in the $\mathrm{MPFC}$, or the ability of haloperidol $(1 \mathrm{mg} / \mathrm{kg})$ to increase dialysate ACh concentrations in the mPFC, NAC, or STR.

\section{DISCUSSION}

The major finding in this study is that, in the absence of AChesterase inhibition, the atypical APDs, clozapine, olanzapine, risperidone, and ziprasidone significantly increased ACh release in the MPFC, but had no effect in the NAC or STR at doses effective in the MPFC. None of the typical APDs, haloperidol, S(-)-sulpiride, or thioridazine significantly increased ACh release in these three regions. Perfusion of neostigmine enhanced the 

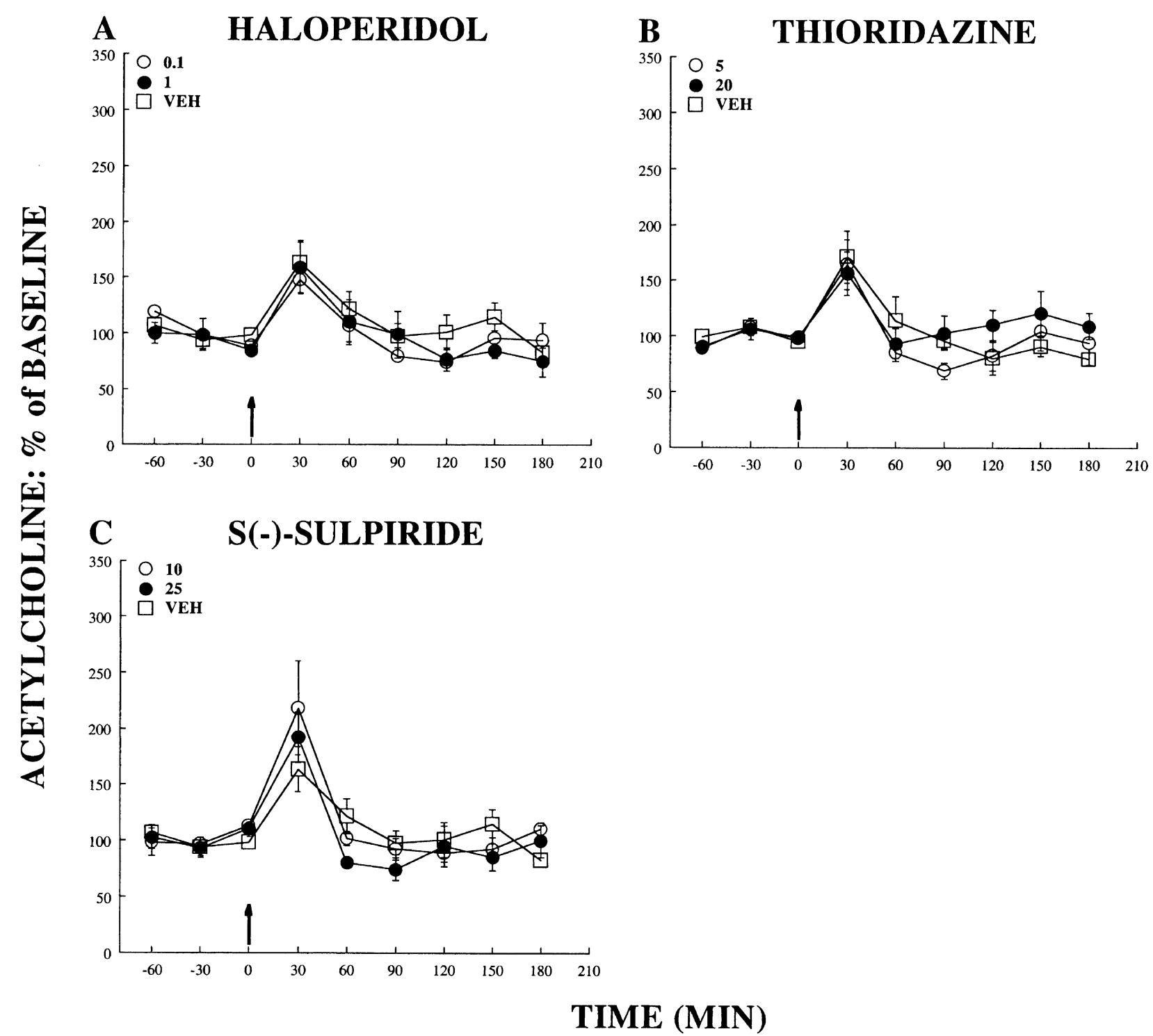

Figure 4. Time-course effects of typical antipsychotic drugs in the medial prefrontal cortex (mPFC), compared with vehicle controls $(\mathrm{VEH}, \square)(\mathrm{N}=6-8)$ in the absence of AChesterase inhibition. Dialysate ACh concentrations were not affected by either haloperidol $(N=6)$ [(A) 0.1 and $1 \mathrm{mg} / \mathrm{kg}$, s.c., $\bigcirc$ and $\boldsymbol{\bullet}$, respectively], thioridazine $(N=6)[(\mathbf{B}) 5 \mathrm{and} 20 \mathrm{mg} / \mathrm{kg}$, s.c., $\bigcirc$ and $\bullet$, respectively], or $S(-)$-sulpiride $(N=5)$ [(C) 10 and $25 \mathrm{mg} / \mathrm{kg}$, s.c., $\bigcirc$ and $\bullet$, respectively].

ability of clozapine, but not haloperidol, to increase $\mathrm{ACh}$ release in these three regions.

The method employed here to measure ACh in the absence of AChesterase inhibition has been described in detail elsewhere (Ichikawa et al. 2000). Tetrodotoxin (TTX), a sodium channel blocker, almost eliminated dialysate ACh before and after clozapine $(20 \mathrm{mg} / \mathrm{kg})$ in the MPFC, NAC, and STR (Figure 1B), indicating a neuronal origin of dialysate $\mathrm{ACh}$ and supporting the conclusion that it reflects ACh release (Di Chiara et al. 1996). The transient increase in ACh release in the mPFC following vehicle may be an injection artifact, which was not found after an indwelling subcutaneous catheter for administering drugs was introduced (data not shown). This injection artifact does not affect the results reported here since the data with or without the putative injection artifact during 30-180-min or 0-180min period, respectively, were not significantly different (Figure 5). Our preliminary data showed that haloperidol $(1 \mathrm{mg} / \mathrm{kg}), \mathrm{S}(-)$-sulpiride $(25 \mathrm{mg} / \mathrm{kg})$, and thioridazine $(20 \mathrm{mg} / \mathrm{kg})$, administered via the indwelling subcutaneous catheter, also had no effect on ACh release in the $\mathrm{mPFC}$, compared to the vehicle (data not shown).

The mechanism(s) by which the anticholinergic drugs and atypical APDs increase cortical ACh release will now be discussed. Blockade of inhibitory $\mathrm{M}_{2}$ autoreceptors (Quirion et al. 1994; Billard et al. 1995; Still- 


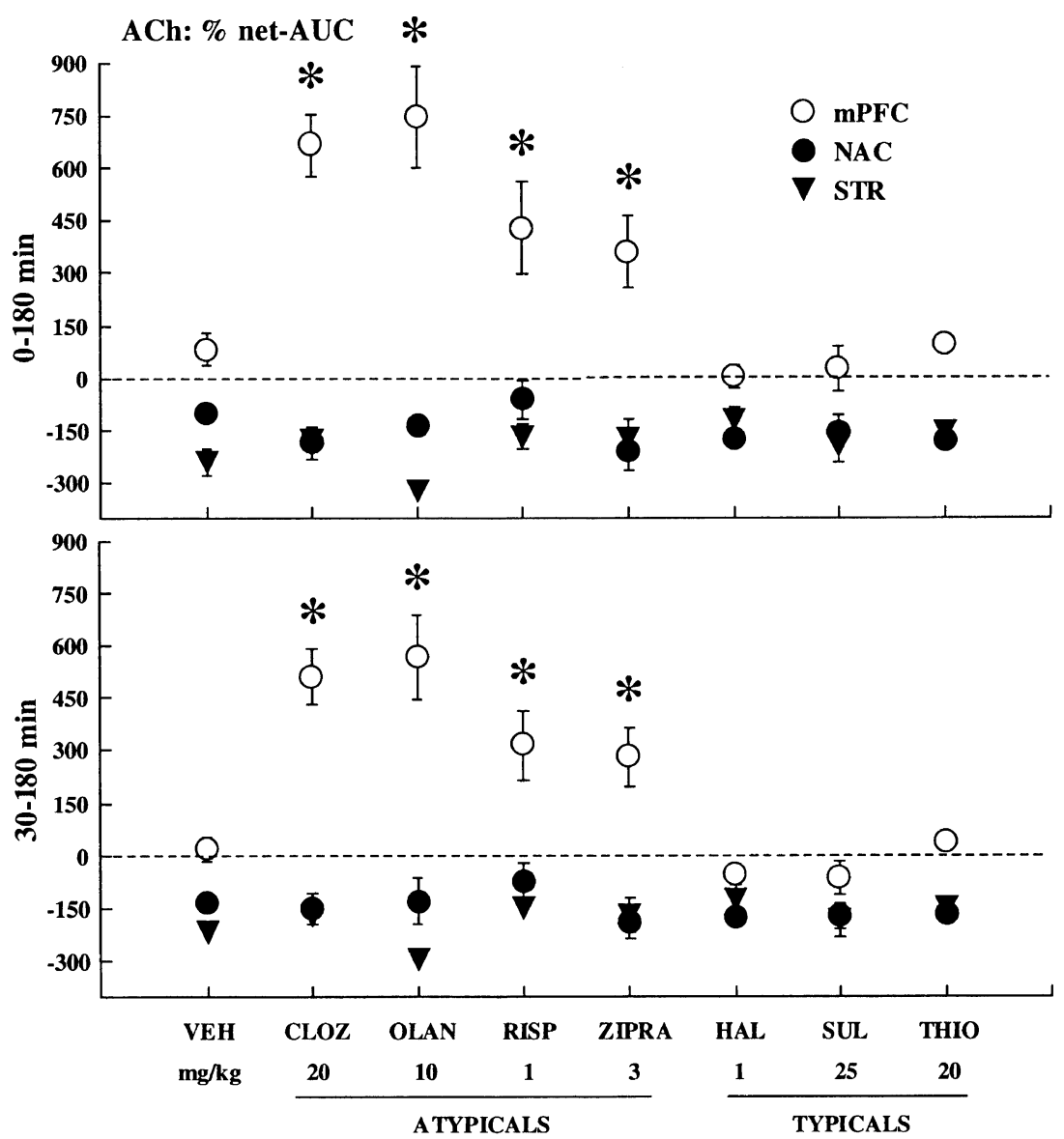

Figure 5. Analysis of \% net-AUC (area under the curve) showed a clear regional difference in the effect of atypical drugs [clozapine (CLOZ), olanzapine (OLAN), risperidone (RISP), and ziprasidone (ZIPR)], and typical antipsychotic drugs (APDs) [haloperidol (HAL), S(-)-sulpiride (SUL), and thioridazine (THIO)], at the highest doses tested in the absence of AChesterase inhibition. Atypical APDs preferentially increased dialysate ACh concentrations in the $\mathrm{mPFC}$, compared to the NAC or STR, whereas typical APDs had no effect. None of these APDs affected dialysate ACh concentrations in either the NAC or STR. Data excluding the effect of injection artifact at $30 \mathrm{~min}$ following injection (lower panel) are virtually identical to the data of a $0-180-m i n$ period (upper panel) with respect to the effect on dialysate ACh concentrations. $N=3-8$.

man et al. 1996; Kitaichi et al. 1999) and stimulation of $\mathrm{M}_{1}$ receptors (Ogane et al. 1990; Murakami et al. 1996; Svensson et al. 1996; Suzuki et al. 1998) have been reported to increase brain ACh release. Thus, it is most likely that the non-selective $\mathrm{mAChR}$ agonist oxotremorine decreased $\mathrm{ACh}$ release in the $\mathrm{MPFC}, \mathrm{NAC}$ and STR via activation of inhibitory $\mathrm{M}_{2}$ autoreceptors, as previously suggested for the STR (De Boer et al. 1990; Westerink et al. 1990; Marshall and Wurtman 1993; Pramanik and Ögren 1993). On the other hand, scopolamine (0.5 $\mathrm{mg} / \mathrm{kg}$ ), a non-selective $\mathrm{mAChR}$ antagonist, which increased ACh release only in the $\mathrm{MPFC}$, may have done so via blockade of $\mathrm{M}_{2}$ autoreceptors in the mPFC (Vannucchi et al. 1997), and possibly the NBM as well, because direct administration of scopolamine $(10 \mu \mathrm{g})$ into the NBM was reported to increase cortical ACh release (Bertorelli et al. 1991).

The failure of scopolamine to increase ACh release in the NAC and STR, where M2 receptors are present (Flynn and Mash 1993; Adem et al. 1997), contrasts with the previous report that scopolamine $(0.1-1 \mathrm{mg} / \mathrm{kg})$ increased ACh release in the NAC (Pfister et al. 1994) and STR (Pramanik and Ögren 1993; Pfister et al. 1994; Scali et al. 1995; Murakami et al. 1996). However, these latter studies were conducted in the presence AChesterase inhibition. The discrepancy suggests possible mecha- nisms. The increased $\mathrm{ACh}$ following scopolamine is most likely due to blockade of $\mathrm{M}_{2}$ autoreceptors, and may be rapidly hydrolyzed by AChesterase. Based upon the ratios of increased $\mathrm{ACh}$ release (Table 2), AChesterase activity may be sufficiently higher in the NAC and STR compared to the mPFC, to hydrolyze any $\mathrm{ACh}$ released by scopolamine in the former two regions, preventing any net increase in extracellular ACh concentrations.

It is also possible that scopolamine increases ACh release in the $\mathrm{mPFC}$ via blockade of inhibitory somatodendritic $\mathrm{M}_{2}$ autoreceptors in the NBM (Bertorelli et al. 1991), which projects cholinergic neurons to the mPFC, but not to the NAC or STR (see the Introduction). Alternatively, it could be argued that the ability of $M_{2}$ receptors to tonically inhibit ACh release in the STR and NAC is relatively weak compared with that in the $\mathrm{mPFC}$. If so, scopolamine can increase $\mathrm{ACh}$ release in the striatum or nucleus accumbens in the presence of AChesterase inhibition that elevates extracellular ACh levels resulting in greater stimulation of $\mathrm{M}_{2}$ receptors. It would be relevant to this hypothesis that clozapine produced greater increases in ACh release in the $\mathrm{MPFC}$, NAC, and STR in the presence of AChesterase inhibition, compared to its absence (present data). Analogous results have been reported for the $D_{2}$ receptor that in- 
CLOZAPINE
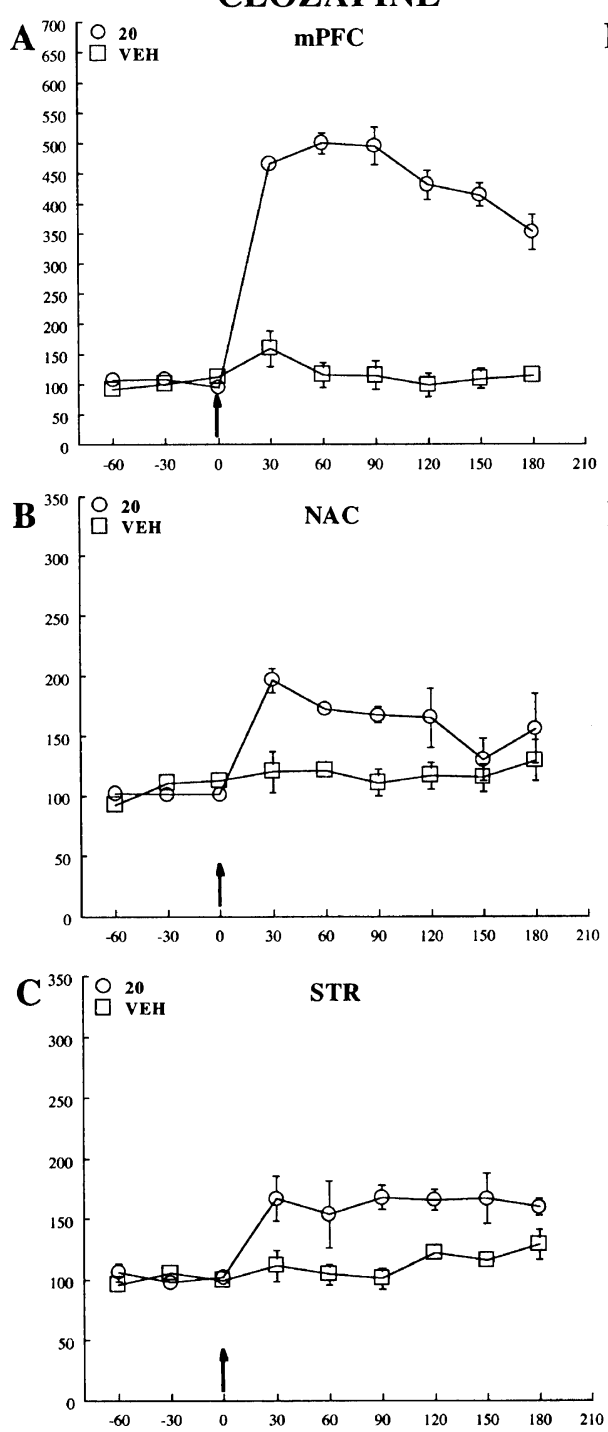

HALOPERIDOL

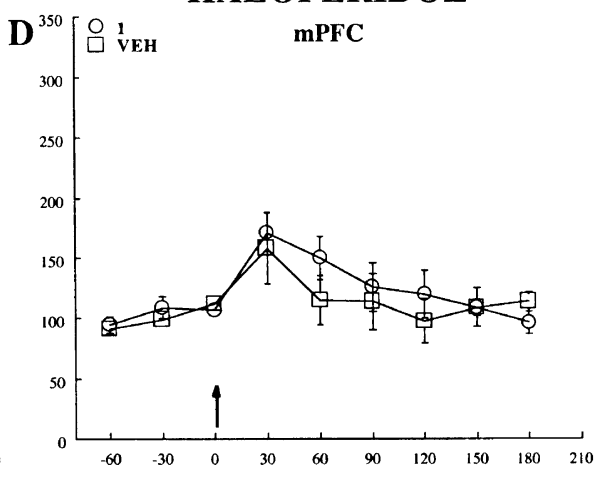

$\mathbf{E}^{350}\left[\begin{array}{lll}\text { 1 } & \text { VEH } \\ \text { VAC }\end{array}\right.$

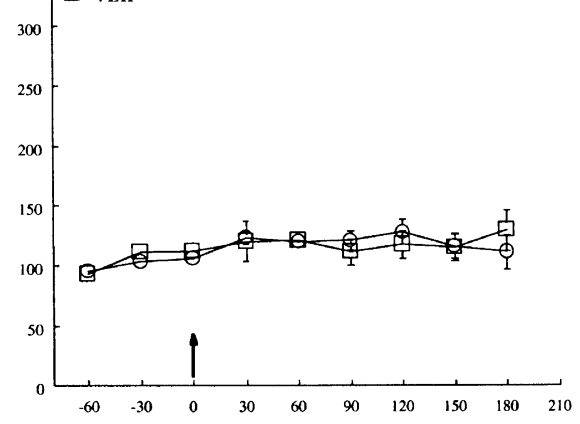

$\mathbf{F}^{350}\left[\begin{array}{ll}0 \\ 0\end{array}\right.$

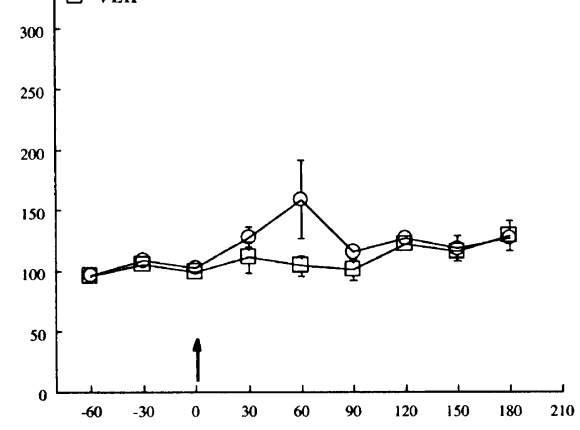

TIME (MIN)

Figure 6. Time-course effects of clozapine and haloperidol in the presence of the AChesterase inhibitor neostigmine $(0.3$ $\mu \mathrm{M})$ in the perfusion medium throughout the experiment after a probe implantation, compared with vehicle controls (VEH, $\square)(N=3-4)$. (A, B) and(C) Clozapine $(20 \mathrm{mg} / \mathrm{kg}$, s.c., $\bigcirc)$ significantly increased dialysate ACh concentrations in the mPFC $(N=4)[(\mathrm{A}) \mathrm{F}(1,6)=173.03, p<.001), \mathrm{NAC}(N=3][(\mathbf{B}) \mathrm{F}(1,5)=9.35, p=.028]$, and STR $(N=4)[(\mathbf{C}) \mathrm{F}(1,6)=16.05, p=$ .007]. (D, E) and (F) haloperidol $(1 \mathrm{mg} / \mathrm{kg}$, s.c., $\bigcirc)$ had no significant effect on dialysate ACh concentrations the $\mathrm{mPFC}(\mathrm{N}=$ 4) $[($ D) $\mathrm{F}(1,6)=0.24, p=.64)$, NAC (E) $(N=4)$, or STR (F) $(N=4)$.

clusion of nomifensine, a DA uptake inhibitor, in the perfusion medium that elevates basal DA levels potentiated the $\mathrm{D}_{2 / 3}$ receptor antagonist raclopride-induced DA release in the mPFC (Westerink et al. 2001), suggesting the relatively weak ability of $\mathrm{D}_{2}$ receptors to tonically inhibit DA release in that region (Ozaki et al. 1989), compared with that in the NAC or STR. We also considered that potential damage of cholinergic neurons by probe implantation, as suggested by a gradual decrease in basal ACh release, could have contributed to the lack of an effect of scopolamine on ACh release in the STR or NAC. However, this seems unlikely, since oxotremorine clearly decreased ACh release in the STR and NAC, and TTX nearly eliminated dialysate ACh, both suggesting neuronal origin of a majority of the dialysate ACh.

The $\mathrm{M}_{1}$ receptor agonists AF102B (Ono et al. 1988) and pilocarpine (Murakami et al. 1996) have been reported to increase ACh release in the STR. Interestingly, pirenzepine, reportedly a $\mathrm{M}_{1}$ receptor antagonist (Moriya et al. 1999), has also been reported to increase ACh release in the STR (De Boer et al. 1990; Billard et al. 
1995; Murakami et al. 1996). Since pirenzepine did not attenuate the effect of pilocarpine, a $\mathrm{M}_{1}$ receptor agonist, on striatal ACh release (Murakami et al. 1996), pirenzepine may be more potent as a $\mathrm{M}_{2}$ receptor antagonist, in vivo, than a $\mathrm{M}_{1}$ receptor agonist, particularly regarding the effect on striatal $\mathrm{ACh}$ release. It should be noted that all of the studies concerning ACh release mechanisms published to date have used agonists and antagonist that are deficient in selectivity. Thus, additional studies with selective drugs, in the absence of AChesterase inhibitors, are needed to delineate the role of $\mathrm{M}_{1}$ and $\mathrm{M}_{2}$ receptors in the regulation of $\mathrm{ACh}$ release in the different brain regions.

Direct effects of some APDs on some mAChRs could be important to their ability to increase ACh release. Clozapine has been reported to be: 1) a $\mathrm{M}_{1 / 2}$ partial agonist (Fritze and Tilmann 1995; Michal et al. 1999); 2) a $\mathrm{M}_{2 / 3 / 5}$ receptor antagonist (Bymaster et al. 1996); and 3) $\mathrm{a} \mathrm{M}_{4}$ receptor full (Zorn et al. 1994; Zeng et al. 1997) or partial agonist (Olianas et al. 1997; Michal et al. 1999). Clozapine and olanzapine may be relatively weaker $\mathrm{M}_{1}$ receptor antagonists in vivo than in vitro (Bymaster and Falcone 2000). Thus, $\mathrm{M}_{2}$ autoreceptor blockade and/or $\mathrm{M}_{1}$ receptor stimulation by clozapine or $\mathrm{M}_{2}$ receptor antagonism by olanzapine (Bymaster et al. 1996) may contribute to their ability to increase $\mathrm{ACh}$ release in the $\mathrm{mPFC}$. However, thioridazine, despite affinity for $\mathrm{M}_{1}$ $(\mathrm{Ki}=2.7 \mathrm{nM})$ and $\mathrm{M}_{2}$ receptors (14) comparable to that of olanzapine (1.9 and 18, respectively) (Table 1), did not increase ACh release in the mPFC. There is little question that thioridazine $(20 \mathrm{mg} / \mathrm{kg})$ gains access to the brain since it increases striatal DA release at the same or similar doses used here (Gainetidinov et al. 1994; Meltzer et al. 1994; Rayevsky et al. 1995). The lack of an effect of thioridazine contrasts the ability of scopolamine, a relatively non-selective $\mathrm{mAChR}$ antagonist, to increase ACh release in the $\mathrm{MPFC}$. Although the discrepancy is not readily reconciled at present, it appears that thioridazine-induced $\mathrm{M}_{1}$ receptor antagonism may negate its $\mathrm{M}_{2}$ receptor antagonist effect on ACh release (Niedzwiecki et al. 1989b). Neither $\mathrm{M}_{2}$ receptor blockade or $\mathrm{M}_{1}$ receptor stimulation is likely to contribute to the effect of risperidone and ziprasidone because they lack affinity for $\mathrm{M}_{1}$ or $\mathrm{M}_{2}$ receptors (Bymaster et al. 1996).

There are many other possible mechanism(s) by which the four atypical APDs, which have a combination of a variety of effects on DA, 5-HT, noradrenergic and other receptors (Table 1), increase ACh release in the mPFC. Potent $5-\mathrm{HT}_{2 \mathrm{~A}}$ relative to weak $\mathrm{D}_{2}$ receptor antagonism, which is a feature common to the atypical APDs, but not to typical APDs (Meltzer et al. 1989; Schotte et al. 1996), may contribute to the ability of these agents to increase ACh release in the $\mathrm{MPFC}$. However, neither $5-\mathrm{HT}_{2 \mathrm{~A}}$ or $\mathrm{D}_{2}$ receptor antagonism alone has any effect on increasing $\mathrm{ACh}$ release in that region:
1) ketanserin, a 5- $\mathrm{HT}_{2 \mathrm{~A}}$ receptor antagonist (Hirano et al. 1995), ritanserin, a 5- $\mathrm{HT}_{2 \mathrm{~A} / 2 \mathrm{C}}$ receptor antagonist (Consolo et al. 1996a; Yamaguchi et al. 1997a,b), and M100907, a selective 5- $\mathrm{HT}_{2 \mathrm{~A}}$ receptor antagonist (Ichikawa et al. in preparation); and 2) S(-)-sulpiride, a $\mathrm{D}_{2 / 3}$ receptor antagonist (present data). $5-\mathrm{HT}_{2 \mathrm{C}}$ receptors are also less likely to contribute to the effect on ACh release because the typical and atypical APDs share in common $5-\mathrm{HT}_{2 \mathrm{C}}$ receptor antagonist properties (Roth et al. 1992; Meltzer, 1999). 5- $\mathrm{HT}_{1 \mathrm{~A}}$ receptor agonists have been reported to increase cortical ACh release (Rada et al. 1993; Consolo et al. 1996b; Somboonthum et al. 1997; Koyama et al. 1999). We have recently suggested that potent $5-\mathrm{HT}_{2 \mathrm{~A}}$ and relatively weak $\mathrm{D}_{2}$ receptor antagonism may promote $5-\mathrm{HT}_{1 \mathrm{~A}}$ receptor agonism (Ichikawa et al. 2001). Clozapine and ziprasidone are also $5-\mathrm{HT}_{1 \mathrm{~A}}$ receptor partial and full agonists, respectively (Newman-Tancredi et al. 1998). Therefore, it is possible that clozapine, olanzapine, risperidone, and ziprasidone may increase $\mathrm{ACh}$ release in the $\mathrm{MPFC}$ via direct and/or indirect 5- $\mathrm{HT}_{1 \mathrm{~A}}$ receptor stimulation.

Clozapine and olanzapine are a $\mathrm{D}_{1}$ receptor partial agonist (Ahlenius 1999) and antagonist (Bymaster et al. 1999), respectively. ACh release could result from $D_{1}$ receptor stimulation secondary to atypical APD-induced DA release in the mPFC (Kuroki et al. 1999; Ichikawa et al. 2001), as has been suggested for the STR (Imperato et al. 1993; De Boer and Abercrombie 1996; Steele et al. 1997). However, this is unlikely in the NAC and STR since the same or similar doses of APDs, clozapine, olanzapine, risperidone, ziprasidone, haloperidol, S(-)sulpiride, and thioridazine increase DA release in the NAC and STR (Meltzer et al. 1994; Ichikawa and Meltzer 2000; Rollema et al. 2000), but do not increase ACh release in these two regions in the present study. It should also be considered that while clozapine is a $D_{1}$ receptor partial agonist (Ahlenius 1999), olanzapine is the antagonist (Bymaster et al. 1999), and both increased cortical ACh release. Antagonism of $\alpha_{1}$ (and perhaps $\alpha_{2}$ ) adrenoceptors may also contribute to the increases in ACh release produced by clozapine, olanzapine, risperidone, and ziprasidone, which have relatively high affinity for one or both of these receptors (Table 1). The $\alpha_{1}$ adrenoceptor antagonist KF-15372 (Kurokawa et al. 1996) and the $\alpha_{2}$ adrenoceptor antagonist idazoxan (Tellez et al. 1997) have both been reported to increase cortical $\mathrm{ACh}$ release.

The discrepancy between the present data and some, but not all, previous findings in other laboratories is due, in large part, to the use of AChesterase inhibitors. For example, clozapine, in the presence of $0.3 \mu \mathrm{M}$ neostigmine, significantly increased ACh release in the mPFC and, to a lesser extent, in the NAC and STR (present data), as previously reported by Parada et al. (1997). The failure of haloperidol to increase ACh release in these three regions with or without $0.3 \mu \mathrm{M}$ neo- 
stigmine (present data), is consistent with the reported inability of haloperidol to increase $\mathrm{ACh}$ release in the $\mathrm{mPFC}, \mathrm{NAC}$, and STR in the presence of 0.5-1 $\mu \mathrm{M}$ neostigmine (Osborne et al. 1994; Moore et al. 1999), but is not consistent with an increase in the STR at doses of $0.125-1 \mathrm{mg} / \mathrm{kg}$ in the presence of AChesterase inhibition (Imperato et al. 1993; De Boer and Abercrombie 1996; Steinberg et al. 1998). Similarly, the lack of an effect of S(-)-sulpiride on ACh release in these three regions (present data) is consistent with the lack of an effect of S(-)-sulpiride $(1 \mu \mathrm{M})$ locally applied in the STR in the presence of AChesterase inhibition (Ueda et al. 1995), but is not consistent with an increase in the STR in the presence of AChesterase inhibition following its systemic (50 mg/ kg) (Imperato et al. 1993) and local administration (0.1-10 $\mu \mathrm{M})$ (Ikarashi et al. 1997). To date, there have been no other microdialysis data of the effects of olanzapine, risperidone, ziprasidone, or thioridazine on ACh release in rat brain, with or without AChesterase inhibition, nor data on the effect of clozapine, haloperidol, and $\mathrm{S}(-)$-sulpiride in the $\mathrm{MPFC}$, in the absence of AChesterase inhibition.

The results reported here demonstrate an important difference in the action of atypical and typical APDs. $\mathrm{M}_{1}$ receptor agonists have been reported to improve working memory in animals (Aura et al. 1997; McDonald et al. 1998) and xanomeline, a $M_{1}$ receptor agonist with minimal $\mathrm{M}_{2}$ receptor blockade (Bymaster et al. 1994; Shannon et al. 1994, 2000), has also improved cognition, and decreased hallucinatory and delusional symptoms in Alzheimer's disease (Bodick et al. 1997; Bymaster et al. 1997) and perhaps schizophrenia, whereas $M_{1}$ receptor antagonists may worsen working memory in patients with schizophrenia (McEvoy 1987; Spohn and Strauss 1989; King 1990) and in animals (Bymaster et al. 1993; Aura et al. 1997; Roldan et al. 1997). The atypical APD-induced cortical ACh release would be expected to increase $\mathrm{M}_{1}$ receptor stimulation by diminishing $\mathrm{M}_{1}$ receptor antagonism where it exists. Clozapine-induced cortical ACh release suggests that it could be worthwhile to study the effect of clozapine and other atypical APDs with AChesterase inhibitors, e.g., donepezil or galanthamine, in the treatment of psychosis and cognitive impairment in senile dementia, Alzheimer's disease, as well as schizophrenia.

In conclusion, the atypical APD, clozapine, olanzapine, risperidone, and ziprasidone, but not the typical APDs, haloperidol, S(-)-sulpiride, or thioridazine, increased ACh release in the $\mathrm{MPFC}$, whereas none did so in the NAC or STR, suggesting cortical ACh may be important to some actions of atypical APDs.

\section{ACKNOWLEDGMENTS}

This study was supported, in part, by grants from the Warren Foundation, Mr. Donald Test, Eli Lilly, and the Pfizer, Inc. We are grateful to Ms. Anna R. Alboszta for an excellent technical assistance.

\section{REFERENCES}

Adem A, Jolkkonen M, Bogdanovic N, Islam A, Karlsson E (1997): Localization of $M_{1}$ muscarinic receptors in rat brain using selective muscarinic toxin-1. Brain Res Bull 44:597-601

Ahlenius S (1999): Clozapine: Dopamine $\mathrm{D}_{1}$ receptor agonism in the prefrontal cortex as the code to decipher a Rosetta Stone of antipsychotic drugs. Pharmacol Toxicol 84:193-196

Aura J, Sirvio J, Riekkinen P (1997): Methoctramine moderately improves memory but pirenzepine disrupts performance in delayed non-matching to position test. Eur J Pharmacol 333:129-134

Bertorelli R, Forloni G, Consolo S (1991): Modulation of cortical in vivo acetylcholine release by the basal nuclear complex: Role of the pontomesencephalic tegmental area. Brain Res 563:353-356

Billard W, Binch H, Crosby G, McQuade RD (1995): Identification of the primary muscarinic autoreceptor subtype in rat striatum as $\mathrm{m} 2$ through a correlation of in vivo microdialysis and in vitro receptor binding data. J Pharmacol Exp Ther 273:273-279

Bodick N, Offen WW, Levey AI, Cutler NR, Gauthier SG, Satlin A, Shannon HE, Tollefson GD, Rasmussen K, Bymaster FP, Hurley DJ, Potter WZ, Paul SM (1997): Effects of xanomeline, a selective muscarinic receptor agonist, on cognitive function and behavioral symptoms in Alzheimer's disease. Arch Neurol 54:465-473

Bolden C, Cusack B, Richelson E (1992): Antagonism by antimuscarinic and neuroleptic compounds at the five cloned human muscarinic cholinergic receptors expressed in chinese hamster ovary cells. J Pharmacol Exp Ther 280: 576-580

Bymaster FP, Heath I, Hendrix JC, Shannon HE (1993): Comparative behavioral and neurochemical activities of cholinergic antagonists in rats. J Pharmacol Exp Ther 267:16-24

Bymaster FP, Wong DT, Mitch CH, Ward JS, Calligaro DO, Schoepp DD, Shannon HE, Sheardown MJ, Olesen PH, Suzdak PD, Swedberg MDB, Sauerberg P (1994): Neurochemical effects of the $\mathrm{M}_{1}$ muscarinic agonist xanomeline (LY246708/NNC11 0232). J Pharmacol Exp Ther 269:282-289

Bymaster FP, Calligaro DO, Falcone JF, Marsh RD, Moore NA, Tye NC, Seeman P, Wong DT (1996): Radioreceptor binding profile of the atypical antipsychotic olanzapine. Neuropsychopharmacology 14:87-96

Bymaster FP, Whitesitt CA, Shannon HE, DeLapp N, Ward JS, Calligaro DO, Shipley LA, Buelke-Sam JL, Bodick NC, Farde L, Sheardown MJ, Olesen PH, Hansen KT, Suzdak PD, Swedberg MDB, Sauerberg P, Mitch CH (1997): Xanomeline: A selective muscarinic agonist for the treatment of Alzheimer's disease. Drug Devel Res 40:158-170

Bymaster FP, Nelson DL, DeLapp NW, Falcone JF, Eckols K, Truex LL, Foreman MM, Lucaites VL, Calligaro DO 
(1999): Antagonism by olanzapine of dopamine $D_{1}$, serotonin 2 , muscarinic, histamine $\mathrm{H}_{1}$ and $\alpha_{1}$-adrenergic receptors in vitro. Schizophr Res 37:107-122

Bymaster FP, Falcone JF (2000): Decreased binding affinity of olanzapine and clozapine for human muscarinic receptors in intact clonal cells in physiological medium. Eur J Pharmacol 390:245-248

Consolo S, Arnaboldi S, Ramponi S, Nannini L, Ladinsky H, Baldi G (1996a): Endogenous serotonin facilitates in vivo acetylcholine release in rat frontal cortex through 5- $\mathrm{HT}_{1 \mathrm{~B}}$ receptors. J Pharmacol Exp Ther 277:823-830

Consolo S, Ramponi S, Ladinsky H, Baldi G (1996b): A critical role for $\mathrm{D}_{1}$ receptors in the $5-\mathrm{HT}_{1 \mathrm{~A}}$-mediated facilitation of in vivo acetylcholine release in rat frontal cortex. Brain Res 707:320-323

Davis KL, Kahn RS, Grant K, Davidson M (1991): Dopamine in schizophrenia: A review and reconceptualization. Am J Psychiatry 148:1474-1486

De Boer P, Damsma G, Fibiger HC, Timmerman W, De Vries JB, Westerink BHC (1990): Dopaminergic-cholinergic interactions in the striatum: The critical significance of calcium concentrations in brain microdialysis. NaunynSchmiedeberg's Arch Pharmacol 342:528-534

De Boer P, Abercrombie ED (1996): Physiological release of striatal acetylcholine in vivo: Modulation by $D_{1}$ and $D_{2}$ dopamine receptor subtypes. J Pharmacol Exp Ther 277:775-783

Di Chiara G, Tanda G, Carboni E (1996): Estimation of invivo neurotransmitter release by brain microdialysis: the issue of validity. Behav Pharmacol 7:640-657

Everitt BJ, Robbins TW (1997): Central cholinergic systems and cognition. Ann Rev Psychol 48:640-684

Flynn DD, Mash DC (1993): Distinct kinetic binding properties of $\mathrm{N}-\left[{ }^{3} \mathrm{H}\right]$-methylscopolamine afford differential labeling and localization of $\mathrm{M}_{1}, \mathrm{M}_{2}$, and $\mathrm{M}_{3}$ muscarinic receptor subtypes in primate brain. Synapse 14:283-296

Fritze J, Tilmann E (1995): Pirenzepine for clozapine-induced hypersalivation. Lancet 346:1034

Fujii T, Yoshizawa M, Nakai K, Fujimoto K, Suzuki T, Kawashima K (1997): Demonstration of the facilitatory role of $8-\mathrm{OH}-\mathrm{DPAT}$ on cholinergic transmission in the rat hippocampus using in vivo microdialysis. Brain Res 761:244-249

Gainetdinov RR, Grekgova TV, Sotnikova TD, Rayevsky KS (1994): Dopamine $D_{2}$ and $D_{3}$ receptor preferring antagonists differentially affect striatal dopamine release and metabolism in conscious rats. Eur J Pharmacol 261: 327-331

Goldman-Rakic PS, Selemon LD (1997): Functional and anatomical aspects of prefrontal pathology in schizophrenia. Schizophr Bull 23:437-458

Hertel P, Fagerquist MV, Svensson TH (1999): Enhanced cortical dopamine output and antipsychotic-like effects of raclopride by $\alpha_{2}$ adrenoceptor blockade. Science 286:105-107

Hirano H, Day J, Fibiger HC (1995): Serotonergic regulation of acetylcholine release in rat frontal cortex. J Neurochem 65:1139-1145

Ichikawa J, Meltzer HY (1999): Relationship between dopaminergic and serotonergic neuronal activity in the frontal cortex and the action of typical and atypical antipsychotic drugs. Eur Arch Psychiatry Clin Neurosci 249(Suppl 4):S90-S98

Ichikawa J, Meltzer HY (2000): The effect of serotonin ${ }_{1 \mathrm{~A}}$ receptors on antipsychotic drug induced dopamine release in rat striatum and nucleus accumbens. Brain Res 858:252-263

Ichikawa J, Dai J, Meltzer HY (2000): Acetylcholinesterase inhibitors are neither necessary nor desirable for microdialysis studies of brain acetylcholine. Curr Separ 19:37-44

Ichikawa J, Ishii $\mathrm{H}$, Bonaccorso S, O'Laughlin IA, Fowler WL, Meltzer HY (2001): 5- $\mathrm{HT}_{2 \mathrm{~A}}$ and $\mathrm{D}_{2}$ receptor blockade increases cortical DA release via of $5-\mathrm{HT}_{1 \mathrm{~A}}$ receptor activation: A possible mechanism of atypical antipsychotic-induced cortical dopamine release. J Neurochem 76:1521-1531

Ikarashi Y, Takahashi A, Ishimaru H, Arai T, Maruyama Y (1997): Regulation of dopamine $D_{1}$ and $D_{2}$ receptors on striatal acetylcholine release in rats. Brain Res Bull 49:107-115

Imperato A, Obinu MC, Casu MA, Mascia MS, Dazzi L, Gessa GL (1993): Evidence that neuroleptics increase striatal acetylcholine release through stimulation of dopamine $\mathrm{D}_{1}$ receptors. J Pharmacol Exp Ther 266:557-562

Imperato A, Obinu MC, Carta G, Mascia MS, Casu MA, Dazzi L, Gessa GL (1994): Neuroleptics cause stimulation of dopamine $D_{1}$ receptors and their desensitization after chronic treatment. Eur J Pharmacol 264:55-60

Kalivas PW, Nakamura M (1999): Neural systems for behavioral activation and reward. Curr Opin Neurobiol 9: 223-227

Kawaguchi Y, Wilson CJ, Augood SJ, Emson PC (1995): Striatal interneurones: Chemical, physiological and morphological characterization. Trend Neurosci 18:527-535

Kawashima K, Sato A, Yoshizawa M, Fujii T, Fujimoto K, Suzuki T (1994): Effects of the centrally acting cholinesterase inhibitors tetrahydroaminoacridine and E2020 on the basal concentration of extracellular acetylcholine in the hippocampus of freely moving rats. NaunynSchmiedeberg's Arch Pharmacol 350:523-528

King DJ (1990): The effect of neuroleptics on cognitive and psychomotor function. Br J Psychiatry 157:799-811

Kitaichi K, Hori T, Srivastava LK, Quirion R (1999): Antisense oligodeoxynucleotides against the muscarinic $\mathrm{m} 2$, but not $\mathrm{m} 4$, receptor supports its role as autoreceptors in the rat hippocampus. Mol Brain Res 67:98-106

Koyama T, Nakajima Y, Fujii T, Kawashima K (1999): Enhancement of cortical and hippocampal cholinergic neurotransmission through $5-\mathrm{HT}_{1 \mathrm{~A}}$ receptor-mediated pathways by BAYx3702 in freely moving rats. Neurosci Lett 265:33-36

Kuroki T, Meltzer HY, Ichikawa J (1999): Effect of antipsychotic drugs on extracellular dopamine levels in rat medial prefrontal cortex and nucleus accumbens. J Pharmacol Exp Ther 288:774-781

Kurokawa M, Shiozaki S, Nonaka H, Kase H, Nakamura J, Kuwana Y (1996): In vivo regulation of acetylcholine release via adenosine a1 receptor in rat cerebral cortex. Neurosci Lett 209:181-184

Leucht S, Pitschel-Walz G, Abraham D, Kissling W (1999): 
Efficacy and extrapyramidal side effects of the new antipsychotics olanzapine, quetiapine, risperidone, and sertindole compared to conventional antipsychotics and placebo. A meta-analysis of randomized controlled trials. Schizophr Res 35:51-68

Marshall DL, Wurtman RJ (1993): Effect of choline on basal and stimulated acetylcholine release: $A n$ in vivo microdialysis study using a low neostigmine concentration. Brain Res 269:353-362

Maura G, Raiteri M (1986): Cholinergic terminals in rat hippocampus possess $5-\mathrm{HT}_{1 \mathrm{~B}}$ receptors mediating inhibition of acetylcholine release. Eur J Pharmacol 129:333-337

McDonald MP, Willard LB, Wenk GL, Crawley JN (1998): Coadministration of galanin antagonist M40 with a muscarinic $\mathrm{M}_{1}$ agonist improves delayed nonmatching to position choice accuracy in rats with cholinergic lesions. J Neurosci 18:5078-5085

McEvoy JP (1987): A double-blind crossover comparison of antiparkinson drug therapy: Amantadine versus anticholinergics in 90 normal volunteers, with an emphasis on differential effects on memory function. Psychopharmacology 119:124-126

Meltzer HY, Matsubara S, Lee J-C (1989): Classification of typical and atypical antipsychotic drugs on the basis of dopamine D-1, D-2 and serotonin2 pKi values. J Pharmacol Exp Ther 251:238-246

Meltzer HY, Chai BL, Thompson PA, Yamamoto BK (1994): Effect of scopolamine on the efflux of dopamine and its metabolites after clozapine, haloperidol or thioridazine. J Pharmacol Exp Ther 268:1452-1461

Meltzer HY, McGurk SR (1999): The effects of clozapine, risperidone, and olanzapine on cognitive function in schizophrenia. Schizophr Bull 25:233-255

Meltzer HY (1999): The role of serotonin in antipsychotic drug action. Neuropsychopharmacology 21(Suppl):106S-115S

Michal P, Lysíková M, El-Fakahany EE, Tucek S (1999): Clozapine interaction with the $\mathrm{M}_{2}$ and $\mathrm{M}_{4}$ subtypes of muscarinic receptors. Eur J Pharmacol 376:119-125

Moore H, Fadel J, Sarter M, Bruno JP (1999): Role of accumbens and cortical dopamine receptors in the regulation of cortical acetylcholine release. Neuroscience 88:811-822

Moriya H, Takagi Y, Nakanishi T, Hayashi M, Tani T, Hirotsu I (1999): Affinity profiles of various muscarinic antagonists for cloned human muscarinic acetylcholine receptor $(\mathrm{mAChR})$ subtypes and $\mathrm{mAChRs}$ in rat heart and submandibular gland. Life Sci 64:2351-2358

Mrzljak L, Pappy M, Leranth C, Goldman-Rakic PS (1995): Cholinergic synaptic circuitry in the macaque prefrontal cortex. J Comp Neurol 357:603-617

Murakami Y, Matsumoto K, Ohta H, Watanabe H (1996): Effects of oxotremorine and pilocarpine on striatal acetylcholine release as studied by brain dialysis in anesthetized rats. Gen Pharmacol 27:833-836

Newman-Tancredi A, Gavaudan S, Conte C, Chaput C, Touzard M, Verrièle L, Audinot V, Millan MJ (1998): Agonist and antagonist actions of antipsychotic agents at $5-\mathrm{HT}_{1 \mathrm{~A}}$ receptors: A $\left[{ }^{35} \mathrm{~S}\right] \mathrm{GTP} \gamma \mathrm{S}$. Eur J Pharmacol 355:245-256

Niedzwiecki DM, Cubeddu LX, Mailman RB (1989a): Comparative antidiopaminergic properties of thioridazine, mesoridazine and sulforidazine on the corpus striatum. J Pharmacol Exp Ther 250:117-125

Niedzwiecki DM, Cubeddu LX, Mailman RB (1989b): Comparative anticholinergic properties of thioridazine, mesoridazine and sulforidazine. J Pharmacol Exp Ther 250:126-133

Ogane N, Takada Y, Iga Y, Kawanishi G, Mizobe F (1990): Effects of a $M_{1}$ muscarinic receptor agonist on the central cholinergic system, evaluated by brain microdialysis. Neurosci Lett 114:95-100

Olianas MC, Maullu C, Onali P (1997): Effects of clozapine on rat striatal muscarinic receptors coupled to inhibition of adenylyl cyclase activity and on the human cloned m4 receptor. Br J Pharmacol 122:401-408

Ono S, Saito Y, Ohgane N, Kawanishi G, Mizobe F (1988): Heterogeneity of muscarinic autoreceptors and heteroreceptors in the rat brain: Effects of a novel M1 agonist, AF102B. Eur J Pharmacol 155:77-84

Osborne PG, O'Connor WT, Beck O, Ungerstedt U (1994): Acute versus chronic haloperidol: Relationship between tolerance to catalepsy and striatal and accumbens dopamine, GABA and acetylcholine release. Brain Res 634:20-30

Ozaki N, Nakahara D, Miura H, Kasahara Y, Nagatsu T (1989): Effects of apomorphine on in vivo release of dopamine and its metabolites in the prefrontal cortex and the striatum, studied by a microdialysis method. J Neurochem 53:1861-1864

Parada MA, Hernandez L, De Parada MP, Murzi E (1997): Selective action of acute systemic clozapine on acetylcholine release in the rat prefrontal cortex by reference to the nucleus accumbens and striatum. J Pharmacol Exp Ther 281:582-588

Paxinos G, Watson C (1986): The Rat Brain in Stereotaxic Coordinates. New York, Academic Press

Perry E, Walker M, Grace J, Perry R (1999): Acetylcholine in mind: A neurotransmitter correlate of consciousness? Trend Neurosci 22:273-280

Pfister M, Boix F, Huston JP, Schwarting RKW (1994): Different effects of scopolamine on extracellular acetylcholine levels in neostriatum and nucleus accumbens measured in vivo: Possible interaction with aversive stimulation. J Neural Transm 97:13-25

Plasky P (1991): Antidepressant usage in schizophrenia. Schizophr Bull 17:649-657

Pramanik A, Ögren SV (1993): Galanin stimulates striatal acetylcholine release via a mechanism unrelated to cholinergic receptor stimulation. Regul Pept 45:353-362

Purdon SE (1999): Cognitive improvement in schizophrenia with novel antipsychotic medications. Schizophr Res 35:S51-S60

Quirion R, Richard J, Wilson A (1994): Muscarinic and nicotinic modulation of cortical acetylcholine release monitored by in vivo microdialysis in freely moving adult rats. Synapse 17:92-100

Rada PV, Mark GP, Hoebel BG (1993): In vivo modulation of acetylcholine in the nucleus accumbens of freely moving rats. I. Inhibition by serotonin. Brain Res 619:98-104

Rayevsky KS, Gainetdinov RR, Grekhova TV, Sotnikova TD (1995): Regulation of dopamine release and metabolism 
in rat striatum in vivo: Effects of dopamine receptor antagonists. Prog Neuropsychopharmacol Biol Psychiatry 19:1285-1303

Roldan G, Bolanos-Badillo E, Gonzalez-Sanchez H, Quirarte GL, Prado-Alcala RA (1997): Selective $M_{1}$ muscarinic receptor antagonists disrupt memory consolidation of inhibitory avoidance in rats. Neurosci Lett 230:93-96

Rollema H, Lu Y, Schmidt AW, Sprouse J, Zorn SH (2000): $5-\mathrm{HT}_{1 \mathrm{~A}}$ receptor activation contributes to ziprasidoneinduced dopamine release in rat prefrontal cortex. Biol Psychiatry 48:229-237

Roth BL, Ciaranello RD, Meltzer HY (1992): Binding of typical and atypical antipsychotic agents to transiently expressed 5- $\mathrm{HT}_{1 \mathrm{C}}$ receptors. J Pharmacol Exp Ther 260:1361-1365

Scali C, Vannucchi MG, Pepeu G, Casamenti F (1995): Peripherally injected scopolamine differentially modulates acetylcholine release in vivo in the young and aged rats. Neurosci Lett 197:171-174

Schotte A, Janssen PFM, Gommeren W, Luyten WHML, van Gompel P, Lesage AS, De Loore K, Leysen JE (1996): Risperidone compared with new and reference antipsychotic drugs: In vitro and in vivo receptor binding. Psychopharmacology 124:57-73

Shannon HE, Bymaster FP, Callgaro DO, Greenwood B, Mitch CH, Sawyer BD, Ward JS, Wong DT, Olesen PH, Sheardown MJ, Swedberg MDB, Suzdak PD, Sauerberg $P$ (1994): Xanomeline: A novel muscarinic receptor agonist with functional selectivity for $\mathrm{M}_{1}$ receptors. J Pharmacol Exp Ther 269:271-281

Shannon HE, Rasmussen K, Bymaster FP, Hart JC, Peters SC, Swedberg MDB, Jeppesen L, Sheardown MJ, Sauerberg P, Fink-Jensen A (2000): Xanomeline, an $\mathrm{M}_{1} / \mathrm{M}_{4}$ preferring muscarinic cholinergic receptor agonist, produces antipsychotic-like activity in rats and mice. Schizophr Res 42:249-259

Somboonthum P, Matsuda T, Asano S, Sakaue M, Baba A (1997): MKC-242, a novel 5- $\mathrm{HT}_{1 \mathrm{~A}}$ receptor agonist, facilitates cortical acetylcholine release by a mechanism different from that of 8-OH-DPAT in awake rats. Neuropharmacology 36:1733-1739

Spohn HE, Strauss ME (1989): Relation of neuroleptic and anticholinergic medication to cognitive functions in schizophrenia. J Abn Psychol 98:367-380

Steele TD, Hodges DB, Levesque TR, Locke KW (1997): $D_{1}$ agonist dihydrexidine releases acetylcholine and improves cognitive performance in rats. Pharmacol Biochem Behav 58:477-483

Steinberg R, Souilhac J, Rodier D, Alonso R, Emonds-Alt X, Le Fur G, Soubrie P (1998): Facilitation of striatal acetylcholine release by dopamine $\mathrm{D}_{1}$ receptor stimulation: Involvement of enhanced nitric oxide production via neurokinin-2 receptor activation. Neuroscience 84:511518

Stillman MJ, Shukitt-Hale B, Galli RL, Levy A, Lieberman HR (1996): Effects of $M_{2}$ antagonists on in vivo hippocampal acetylcholine levels. Brain Res Bull 41:221-226

Suzuki T, Hirooka K, Kanda K, Uesaka H, Hirooka H, Furu- sawa K (1998): Characterization of the neurochemical effects of N-[2-(1-azabicyclo[3,3,0]octan-5-yl)ethyl]2nitroaniline fumarate (SK-946) as a cognition activator. Biol Pharm Bull 21:704-709

Svensson AL, Zhang X, Nordberg A (1996): Biphasic effect of tacrine on acetylcholine release in rat brain via $\mathrm{M}_{1}$ and $\mathrm{M}_{2}$ receptors. Brain Res 726:207-212

Tanda G, Carboni E, Frau R, Di Chiara G (1994): Increase of extracellular dopamine in the prefrontal cortex: a trait of drugs with antidepressant potential? Psychopharmacology 115:285-288

Tandon R, De Quardo JR, Goodson J, Mann NA, Greden JF (1992): Effect of anticholinergics on positive and negative symptoms in schizophrenia. Psychopharmacol Bull 28:297-302

Tandon R (1999): Cholinergic aspects of schizophrenia. Br J Psychiatry 174(Suppl 37):7-11

Tellez S, Colpaert F, Marien M (1997): Acetylcholine release in the rat prefrontal cortex in vivo: modulation by alpha2-adrenoceptor agonists and antagonists. J Neurochem 68:778-785

Ueda H, Sato K, Okumura F, Misu Y (1995): L-DOPA inhibits spontaneous acetylcholine release from the striatum of experimental Parkinson's model rats. Brain Res 698: 213-216

Vannucchi MG, Scali C, Kopf SR, Pepeu G, Casamenti F (1997): Selective muscarinic antagonists differentially affect in vivo acetylcholine release and memory performances of young and aged rats. Neuroscience 79:837-846

Westerink BHC, De Boer P, Damsma G (1990): Dopamineacetylcholine interaction in the striatum studied by microdialysis in the awake rat: Some methodological aspects. J Neurosci Met 34:117-124

Westerink BHC, Kawahara Y, De Boer P, Geels C, De Vries JB, Wikström HV, Van Kalkeren A, Van Vliet B, Kruse CG, Long SK (2001): Antipsychotic drugs classified by their effects on the release of dopamine and noradrenaline in the prefrontal cortex and striatum. Eur J Pharmacol 412:127-138

Winkler J, Suhr ST, Gage FH, Thal LJ, Fisher LJ (1995): Essential role of neocortical acetylcholine in spatial memory. Nature 375:484-487

Yamaguchi T, Suzuki M, Yamamoto M (1997a): Evidence for $5-\mathrm{HT}_{4}$ receptor involvement in the enhancement of acetylcholine release by p-chloroamphetamine in rat frontal cortex. Brain Res 772:95-101

Yamaguchi T, Suzuki M, Yamamoto M (1997b): Facilitation of acetylcholine release in rat prefrontal cortex by indeloxazine hydrochloride: Involvement of endogenous serotonin and 5- $\mathrm{HT}_{4}$ receptors. Naunyn-Schmiedeberg's Arch Pharmacol 356:712-720

Zeng XP, Le F, Richelson E (1997): Muscarinic m4 receptor activation by some atypical antipsychotic drugs. Eur J Pharmacol 321:349-354

Zorn SH, Jones SB, Ward KM, Liston DR (1994): Clozapine is a potent and selective muscarinic $\mathrm{M}_{4}$ receptor agonist. Eur J Pharmacol Mol Pharmacol Sec 269:R1-R2 